\title{
David Oliver: Values statements aren't worth the paper
}

\author{
David Oliver consultant in geriatrics and acute general medicine
}

Berkshire

In A Sceptic's Medical Dictionary, the great Michael O'Donnell made mischievous fun of mission statements in the NHS, calling them "pious utterances trusts print below their expensively commissioned logo." Values statements are close siblings; both are ubiquitous in health and social care. ${ }^{2}$

There's nothing wrong with publicising your guiding values. But I suspect that most patients and families would prefer to experience these in the way they're treated rather than see them written on leaflets, posters, and letterheads.

Too often, statements are platitudinous - who could disagree with them? You can test this by saying the opposite, to see how daft it sounds. For example, try NHS England's six Cs of nursing: care, compassion, courage, communication, commitment, and competence. ${ }^{3}$ Very good, but who would value carelessness, callousness, cowardice, or incompetence?

Skilled, compassionate, caring practitioners and teams are legion in the NHS, but certainly not because of meaningless mantras. There's a surfeit of worthy spiel about good care being dignified, person centred, personalised, putting people first, respecting choice, and so on. But does this describe the care our pressurised, underfunded, and fragmented systems allow us to provide?

The brilliant Dignity in Practice study was based on detailed observation of ward care for older people. ${ }^{4}$ These observations centred on failing to see patients as individuals and prioritising system priorities, procedures, and pressures from managers. ${ }^{4}$

Here are some things, that in my experience we still do far too often:

- Move people around hospitals, sometimes repeatedly, at cost to them personally, to continuity, to communication, and to bed occupancy and flow ${ }^{56}$

- Allow people in subacute crises to be admitted by default into overcrowded hospitals for want of an adequate community response $\mathrm{e}^{78}$

- Pass referrals to intermediate care services in the community in ways too often designed around what providers want rather than what patients really need ${ }^{7}$
- Maroon patients in beds while health and social services argue about funding and take days or weeks to set up meetings or put the case before a funding panel ${ }^{9} 10$

- Argue over means tested packages of social care compared with NHS community rehabilitation, while the patient and family sit bewildered by the difference

- Refuse to take patients back into their residential homes from hospital until they've been reassessed, days after they needed to leave, or refusing them back ever because of needs that were apparent before hospital admission.

Do these represent the person centred values we espouse? Many of these problems indicate a system under extreme funding and workforce pressure. ${ }^{112}$ But "putting people first," they are not. We all need to do better at living up to mission statements, or they're not worth the paper they're written on.

Competing interests: See www.bmj.com/about-bmj/freelancecontributors/david-oliver.

Provenance and peer review: Commissioned; not externally peer reviewed.

O'Donnell M. A sceptic's medical dictionary. BMJ, 1997.

2 McNamara C. Basics of developing mission, vision and values statements. http $/ /$ managementhelp.org/strategicplanning/mission-vision-values.htm.

3 Stephenson J. NHS England to roll out "6 Cs" nursing values to all trusts. Nurs Times 2014 Apr 23. www.nursingtimes.net/roles/nurse-managers/exclusive-6cs-nursing-valuesto-be-rolled-out-to-all-nhs-staff/5070102.fullarticle.

4 Tadd W, Hillman A, Calnan S, Calnan M, Bayer A, Read S. Dignity in practice: an exploration of the care of older adults in acute NHS trusts (a research summary). NIHR Service Delivery and Organisation Programme. 2011. www.cardiff.ac.uk/socsi/dignity/ dignityinpractice/cesagen-dip-research-summary.pdf.

5 McMurdo MET, Witham MD. Unnecessary ward moves. Age Ageing 2013;42:555-6.pmid: 23892919.

6 Cornwell J, Levenson R, Sonola L, Poteliakhoff E. Continuity of care for hospital patients: a call for action. King's Fund. 2012. www.kingsfund.org.uk/sites/files/kf/field/field_ publication file/continuity-of-care-for-older-hospital-patients-mar-2012.pdf.

7 NHS Benchmarking Network. National audit of intermediate care summary report. 2015 www.nhsbenchmarking.nhs.uk/CubeCore/.uploads/NAIC/Reports/ NAICReport2015FINALA4printableversion.pdf.

8 Imison C, Poteliakhoff E, Thompson J. Older people and emergency bed use: exploring variation. King's Fund. 2012. www.kingsfund.org.uk/sites/files/k/field/field_publication file/older-people-and-emergency-bed-use-aug-2012.pdf.

9 NHS Benchmarking Network. Older people's care in acute settings: dashboard report 2015-16 work programme. 2016 https://gallery.mailchimp.com/ 85b1893e69ce6351351ec4385/files/OP_Care_in_Acute_Settings_OP000.pdf.

10 Thompson J. Delayed transfers of care: join the queue. King's Fund. 2015. www.kingsfund. org.uk/blog/2015/11/delayed-transfers-care-join-queue. 
11 Oliver D. We cannot keep ignoring the crisis in social care. BMJ 2015;350:h2684. doi:10. 1136/bmi.h2684 pmid:25999479.

12 Ham C. Jeremy Hunt is in trouble. This is his IDS moment. Guardian 2016 Apr 7. www. theguardian.com/commentisfree/2016/apr/07/jeremy-hunt-in-trouble-ids-moment.
Published by the BMJ Publishing Group Limited. For permission to use (where not already granted under a licence) please go to http://group.bmj.com/group/rights-licensing/ permissions 